\title{
WOMEN'S COMMENSALITY IN THE ANCIENT GREEK WORLD
}

\author{
By JOAN BURTON
}

\section{Introduction}

Dining and drinking rituals in the ancient world have been the subject of much recent discussion, and the significance of these rituals, particularly for males, has been extensively studied. ${ }^{1}$ Scholars have often slighted the topic of women's part in the history of ancient Greek dining and drinking parties, however, and the broad generalization 'Citizen women were never present at Greek symposia' is not uncommon. ${ }^{2}$ Admittedly, women other than hetairai, slaves, hired entertainers, etc., are not conspicuous in the evidence from which we must draw our history of ancient Greek symposia. The evidence, however, both written and visual, was created and preserved predominantly by males. Also, the view that there was a fairly narrow participation of women often seems based largely on evidence taken from fifth and fourth century B.C. Athens. ${ }^{3}$ Yet the roles of women at Greek dining and drinking parties changed over time and place. ${ }^{4}$ This paper provides a survey, with examples, of the variety of women's dining occasions from the Homeric through to the Hellenistic age. The aim of this survey is to emphasize the value of paying closer attention to the female side of wining and dining in our discussions of occasions of commensality in the ancient Greek world.

Why should we care about women's participation at drinking and dining parties? In part because their presence or absence signifies presence or absence in a venue where deals were made, political and social linkages established, ideas discussed. The symposium ${ }^{5}$ was one of the central social institutions of the ancient world, and how people felt about it in part signified their social class and political views (elitist versus democratic). How these views changed over time and place and how the institution changed over time and place underscore changes in political and social life and in the relationships between men and women in the ancient world. Further, the participation of women in the history of Greek commensality does not depend solely on female presence at 
male-defined symposia. Just as men had a wide range of venues in which they might socialize with one another, including public banquets (many of them religious), ${ }^{6}$ so too women. This paper emphasizes the importance of opening up the consideration of women's commensality beyond the male-defined symposium.

The paper is organized as follows. Section 1 examines women's participation in dining occasions in the Homeric and heroic worlds. We start with this topic because of the legendary nature of these worlds and also the importance given to Homeric values by later Greeks. The rest of the paper is organized thematically and concentrates on the archaic through to the Hellenistic periods. Section 2 shows cases where respectable women attended dining gatherings dominated by men. Section 3 explores occasions when women drank and dined together without men. Section 4 looks at cases of women's feasts that also included men. Section 5 shows women in positions of power at dining parties that included men. Section 6 focuses on occasions when men and women seem to have feasted on fairly equal terms.

The evidence includes court cases, histories, biographies, travel texts, moral treatises, sympotic literature, inscriptions, scholia, and works of visual art, as well as poetry, plays, and fictive letters. Caution must be exercised in reading all of this material. I have tried to be selective; my aim is merely to suggest that the aggregation of evidence here offers a more comprehensive glimpse of the range of women's commensal activities. A few words should perhaps be said about the use of fictional works in particular. Our evidence for women's life in the ancient Greek world is limited, and many of our glimpses into women's lives come only in works of fiction. The interpretation of depictions of women's life that appear in fictional works is a very delicate matter, but we should not disregard such depictions, particularly as supplements to other evidence. The humour of the action in such genres as New Comedy, for example, which focuses on events of daily life, seems to depend in large part on audience recognition (from daily life) of social attitudes and modes of behaviour depicted on stage.

\section{Dining among the Homeric Heroes and the Gods}

In the Homeric world, as Murray has shown, elite warriors seem to have established a system of reciprocal banquets held in great halls, which served to maximize the number of potential allies. ${ }^{8}$ Yet noblewomen too 
could appear at these banquets. Further, not only could respectable women attend dining and drinking parties that included males outside the family, but they could also play powerful roles at these parties. For example, when the stranger Odysseus arrives among the Phaeacians, Arete is presiding with her husband at a banquet attended by Phaeacian nobles and leaders (Od. 7.136-43), and it is to her that Odysseus has been instructed to appeal for passage home (Od. 6.303-15, 7.53-77). Arete's freedom to attend feasts that include male guests and strangers is not unique to her in the Homeric texts. Helen, in her Spartan home after her return from Troy, offers a key example of a woman who actively participates in drinking parties that include male strangers. When two male strangers arrive at her home (Telemachus and a friend), Helen takes the lead in the drinking party: she directs the serving of the wine and suggests storytelling for the entertainment. She takes advantage of the social occasion to try to bolster her reputation by retelling the story of her encounter with Odysseus and by stressing her loyalty to Menelaus (Od. 4.219-64). Thus Helen uses the forum of the dinner party for political purposes: to try to rebuild her reputation, to try to limit damage from her adulterous journey to Troy.

Respectable females other than the matron of the house also make appearances at dining and drinking gatherings in the Homeric world. For example, among the Phaeacians, Nausicaa seems not excluded from the feasting space, for when Odysseus attends a feast in the great hall, he passes by her standing at a pillar and she greets him (Od. 8.457-62). So too at Ithaca, Penelope, a matron of the house, unwilling to join the unruly suitors feasting in her great hall, none the less is willing to show herself and even address them (Hom. Od. 16.409-33, 18.206-80, 21.57-79). Also in Greek tragedies depicting the heroic world, respectable women participate in feasts attended also by men. Thus in Aeschylus' Agamemnon, Agamemnon's daughter Iphigenia, according to the chorus, entertained at Agamemnon's dining and drinking parties by singing paeans (243-7)..$^{9}$ In Euripides' Electra, Clytemnestra is expected to attend a sacrificial feast with her consort Aegisthus and male retainers of the household (640-4), and Aegisthus also invites male strangers (Pylades and Orestes in disguise) to the feast. In Sophocles' Oedipus the King, in Oedipus' household daughters regularly joined their father at meals, as shown by Oedipus' lament to Creon: 'my two girls ... whose table never stood apart from mine, and everything I touched they always shared' (1463-5; tr. D. Grene).

Among the Homeric gods too, females and males traditionally dine 
together. As among humans, so also at divine drinking and dining gatherings friendships are established, political alliances are created, and plots are hatched. For example, in Homer's Iliad, at a feast of gods and goddesses, in Zeus's absence, Hera displays her power by speaking against Zeus's actions (15.96-112), and she succeeds in provoking Ares to defy Zeus's orders that the gods stay out of the combat around Troy (113-20). Female deities seem to be presiding over this divine feast: Themis is first among the feasters to meet Hera, Hera takes the cup from her, and Hera bids her to begin the 'equal feast' (15.95). Also, at the close of the Iliad Book 1, the gods and goddesses are reconciled after Hera's fierce quarrel with Zeus by drinking and feasting together. The Greek deities' gender-egalitarian approach to assembling (and feasting) together is also illustrated on the east frieze of the Athenian Parthenon, where male and female gods are represented sitting side by side, talking with one another. ${ }^{10}$

We begin with this survey of Homeric formulations of gender behaviour at dining and drinking parties since, for the Greeks, the Homeric epics, memorized at school and recited at public festivals, were not only art but also models for life (e.g., how to make sacrifices, kill enemies, welcome guests). What did it mean to different Greeks to hear these stories and repeat these paradigms of behaviour? Might Greek women have responded to these stories differently from Greek men? How might they have listened with a differently tuned attention? ${ }^{11}$ And more importantly for this paper, did the Homeric model of male-female conviviality survive in the later Greek world, typically thought to exclude respectable women from drinking and dining parties?

\section{Women Attending Men's Parties}

During the archaic period, when the new hoplite fighting force was expanding the sense of entitlement beyond the aristocratic class, Greek male aristocrats began to hold small, elitist, male-defined, after-dinner drinking parties, which helped preserve their sense of social exclusivity and superiority, in part through the adoption of luxurious customs, such as reclining on couches. ${ }^{12} \mathrm{~A}$ male aristocrat's sense of privilege and identity was also reinforced at these gatherings by the ministrations of attractive young persons, both male and female. Another bolster to the male aristocratic ego may have been provided by acts of violence, often sexual, committed against hired and slave women in attendance at 
symposia, ${ }^{13}$ although in time public opinion seems to have moved against such arrogant behaviour. ${ }^{14}$ Further, by the fourth century B.C., legal speeches in Athens would cite a woman's presence at such parties as proof that she must have been a prostitute, ${ }^{15}$ which seems to reinforce the supposition that respectable women were not generally welcome at traditionalist, male-defined dinner parties and symposia, at least during the classical period in Athens. When scholars today mention women at Greek symposia, they are thinking typically of hetairai, as well as female slaves and other hired entertainers, as represented mainly on painted pottery and in comic writings and legal speeches from Athens. ${ }^{16}$

A famous statement from Cornelius Nepos' 'Preface' (first century B.C., Rome) is often cited to support the supposition that respectable women were excluded from Greek dinner parties: 'Many actions are seemly according to our code which the Greeks look upon as shameful. For instance, what Roman would blush to take his wife to a dinnerparty? . . . But it is very different in Greece; for there a woman is not admitted to a dinner-party, unless relatives only are present'. ${ }^{17}$ Yet the final qualifying phrase is worth more notice, for it indicates that Greek women could attend dinner parties that included only relatives as guests. A fragment from a play of Menander's from fourth-century B.C. Athens describes such an extended-family dinner party, including a young man, his father and mother, an old aunt, the aunt's father, and another old woman. This sympotic party features wine-drinking and instructive talk addressed to a young man, with the father taking the wine-cup and leading the talk, followed by the other adults (both male and female), each addressing the young man in turn. ${ }^{18}$

Another bit of evidence often cited in discussions of women at dining gatherings is an argument the orator Isaeus made against a woman's respectability (fourth century B.C., Athens): 'nor do married women accompany their husbands to dinners or think of feasting in the company of strangers, especially mere chance comers' (3.14). ${ }^{19}$ But when scholars cite this statement in support of the belief that respectable women were excluded from Greek feasting, they generally disregard the final clause 'especially mere chance comers'. Yet the addition of this clause seems to suggest that married women might have attended feasts in the company of male strangers who were not 'chance comers'. ${ }^{20}$ Further, Isaeus' statement also seems to suggest that married women might think of feasting in the company of male acquaintances.

Several anecdotes concerning philosophers suggest that respectable women were not unknown at convivial gatherings that would have 
included male strangers or acquaintances (not kin). For example, there is Hipparchia, an upper-class Greek woman of the early third century B.C., from Maroneia (in southern Thrace), who contrary to her parents' wishes married the Cynic philosopher Crates. ${ }^{21}$ Afterwards, they lived as itinerants, preaching the life of poverty, consoling the sick and unhappy. Dependent for meals on the kindness of strangers, they were admired by some as a novelty and also by some for their selfless ideals. Hipparchia thus lived a life far different from the usual upperclass Greek woman: she was an itinerant with her husband, sworn to poverty, and much in the public eye. Most importantly for us, she is said to have regularly attended dinners and symposia with her husband. This reportedly sometimes led to unpleasant encounters with men unaccustomed to dining in the company of outspoken well-born women. For example, at King Lysimachus' symposium, when she used logic to put down a male philosopher, he responded by pulling up her cloak (Diog. Laert. 6.98).

Another brilliant, iconoclastic woman worthy of note in the history of women at dinner parties is Aspasia, who came to Athens from Miletus in Asia Minor shortly before 445 B.C. and lived with the general and statesman Pericles. As an outlander in Athens, Aspasia reportedly became friends with such notables as Socrates and might well have attended dinner parties at which Socrates was present (see, e.g., Plut. Per. 24.3; Ath. 569f). I mention Aspasia here, although she has the reputation of having worked as a hetaira and a bawd, ${ }^{22}$ because of her unusual status as a woman of visibility and influence in fifth-century Athens.

Other examples of women who might have attended philosophers' dinner parties include two students of Plato: Lastheneia of Mantinea and Axiothea of Phlius (Diog. Laert. 3.46). For Axiothea at least, the awkwardness of being a woman at male-dominated gatherings may have been diminished, since she reportedly dressed in men's clothing. Two other philosophical communities (in addition to the Cynics, as noted above) were remarkably open to women: the Pythagoreans, from the late sixth century B.C. on, mostly in Greek communities in southern Italy, and the Epicureans, starting in the fourth century B.C. ${ }^{23}$ Women who lived, studied, and practised philosophy with men in these communities would probably have eaten with them as well. ${ }^{24}$

Also, even in fifth-century Athens, private celebrations of mysteries may not have been necessarily gender-exclusive. For example, as Pomeroy suggests, Agariste (Alcmaeonides' wife), who provides key 
testimony against Alcibiades, may have actually witnessed the mysteries held in Charmides' house. ${ }^{25}$

Many factors contributed to a loosening of gender and class restrictions in the Hellenistic period. Alexander the Great's conquests had brought dramatic changes to the Greek world: autocratic hegemonies were ascendant, mobility (both social and geographic) was on the rise, and the ideal of the citizen-soldier was fading. But while male political life was in decline (in a world ruled by kings), evidence shows that the horizon of social roles for Greek women was expanding. For example, the honours given to women for artistic achievements and civic endowments attest to the economic power and visibility of Hellenistic Greek women. ${ }^{26}$ At the highest levels, strong queens such as Berenice I and Arsinoe II were displaying authority and power in the public sphere by such acts as sponsoring temples and festivals. ${ }^{27}$ Also, the use of marriage contracts, which protected a woman's interests even in the absence of family, could allow women more mobility and independence. $^{28}$

Some of the poetry written during Hellenistic times seems to reflect a relaxation of gender and class restrictions at symposia in the Hellenistic period. ${ }^{29}$ A key example is Theocritus' Idyll 14, which features a symposium specifically set in Hellenistic times (the host is advised at the poem's end to move to Ptolemy's Egypt). The symposium's guests, who include a Thessalian horse-trainer and a soldier, show that the nonelite symposium was not unknown in Hellenistic times. The non-elite nature of this symposium is also suggested by the host's resolve, at the poem's end, to forget the past by becoming a mercenary soldier. ${ }^{30}$ Further, the defiant actions of Cynisca, the woman guest at Idyll 14's symposium, against the sympotic host suggest that she was neither hired nor a slave. Although the host expects her to toast him as her lover, she does not. When he discovers the reason for her refusal (she has transferred her affection to another), he angrily beats her, and she responds by leaving the party. Cynisca asserts her autonomy of the host's authority not only by exercising choice in whom she loves but also by leaving the symposium. ${ }^{31}$ Thus, at least by the third century B.C., as Cameron notes, 'we need not automatically assume that any woman present at a symposium was a hetaira. ${ }^{32}$

Respectable women may also have participated in certain sacrificial feasts over which men presided, as suggested in some cases by the distribution of sacrificial meat to women. Although such distributions did not always imply women's presence at the sacrificial feast (the 
female basketbearers at the Panathenaia, for example, received shares of the sacrificial meat, but probably did not also participate in the feast), ${ }^{33}$ still there are cases of distributions of sacrificial meat to women that suggest the possibility of participation in the feast as well. For example, a decree of Athenian orgeones (members of a religious association), dating from the early third century B.C., specifies that sacrifices made on the 17th and 18th of Hekatombaion to the heroines and hero were to be distributed to males and females in similar proportions: whole shares to orgeones present and to free women; no more than half shares to sons, daughters, and female attendants; the women's portions to be delivered to the men. ${ }^{34}$ Ferguson proposes that since these orgeones had to be present to receive shares, the women did also; that the women's portions were delivered to the men only to make the distribution easier; and further, that the celebrants, as at the sacrifices of the Attic orgeones of Ergetes, would have feasted 'on the spot'. ${ }^{35}$ Also, an earlier inscription from Thasos, dating about $470 \mathrm{~B}$.C., shows women receiving shares at a sacrifice: the biennial sacrifice for Athena Patroia. ${ }^{36}$ So too at Athens, during the Oschophoria, women called Deipnophoroi (dinner-carriers) participated in the procession and shared in the sacrifice. ${ }^{37}$ Also, public festivals of Dionysus such as the Anthesteria and the rural Dionysia included both men and women and involved rites of sacrifice. ${ }^{38}$

\section{Women Only}

Women also held their own parties in the ancient Greek world; this section focuses on female-defined drinking and dining gatherings that excluded men. Some of these female gatherings were fairly casual. Thus, for example, Pindar's Pythian 9 (for Telesicrates of Cyrene) cites as key examples of womanly activities: to work the loom and to share meals with female friends (18-19; instead the nymph Cyrene hunts). Remarks in Greek comedy also suggest that women might invite one another for meals during the day: for example, a man in Aristophanes' Ecclesiazusae speculates that his neighbour's missing wife might be having breakfast with a female friend (348-9). Menander even wrote a comedy called Sunaristosai, 'Ladies Who Lunch Together' (Ath. 248a). ${ }^{39}$ But in the ancient Greek world, where women were typically denied such modes of self-expression as voting in civic elections or serving on juries, women's religious festivals and celebrations also provided important opportunities (both formal and informal) for 
women to establish a sense of self-identity and community; and feasting and drinking together played a significant role in this process of socialization.

One of the most widely spread Greek women's festivals was the Thesmophoria, an autumn festival in honour of Demeter. ${ }^{40}$ In Athens, this festival lasted three days, and the third day featured a statesponsored women's feast. The women elected female officials to preside, and wealthy women sponsored the feast (at their husbands' expense) for other women from their demes. ${ }^{41}$ These feasts, supported by the male citizenry and integrated into the city-state's calendar, provided an occasion for women to socialize together en masse, apart from men. Comic playwrights exploited male anxieties about what women might do and say at such gatherings: in Aristophanes' Thesmophoriazusae, for example, women plot at the Thesmophoria to kill the tragic playwright Euripides. Women sacrificed and feasted together at other celebrations of Demeter. Thus, for example, Pausanias reports the story that during the second Messenian war, in the mid-seventh century B.C., women celebrating a festival of Demeter in Aigila, Lakonia, attacked the rebel Aristomenes and his men with the knives and spits that they used to slaughter and roast the sacrificial victims. ${ }^{42}$

Another festival featuring a women's feast and also signifying at least a temporary opposition to men is the Skira, a summer festival associated with both Demeter and Athena. During this festival women ate garlic, a pungent food linked with sexual abstinence. A women's assembly seems to have been part of this festival as well, with select women in charge (Ar. Thesm. 834), and in Aristophanes' Ecclesiazusae, Praxagora reports that the women drafted their plans against the men during the Skira festival (18). ${ }^{43}$

A more bawdy festival featuring women's feasting was the Haloa, an all-night midwinter festival honouring Demeter and Dionysus. At Eleusis, the archons provided the celebrant women with wine and foodstuffs, which included dough shaped like genitals, and the women feasted together within the sanctuary, supposedly telling ribald jokes to one another, while the men stayed outside. ${ }^{44}$ Celebrant women seem to have been expected to make contributions toward this feast also, as suggested in Lucian Dial. Meret. 7.4, where a mother asks her daughter what her male lover has given her for the Haloa feast.

Another example of a women's feast that excluded men took place at Tegea, in Arcadia, in honour of Ares Gunaikothoinas (feaster of women). Pausanias emphasizes that women performed the sacrifice 
for this feast and that no shares of sacrificial meat were distributed to the men (Paus. 8.48.4-5). ${ }^{45}$ Also at Perge, in Pamphylia, third century B.C., a public sacrifice was performed (and consumed) by the priestess of Artemis and the prytaneis' wives. ${ }^{46}$

Further, excavations have uncovered banquet rooms at sites of women's worship (such as Brauron and the sanctuary of Demeter at Corinth) ${ }^{47}$ Also, every four years at the Heraia in Olympia, the maidens who won the running contests received shares of the sacrificial ox as awards, and sixteen women, with female attendants, were in charge of the festivities (Paus. 5.16.2-3), which may have included a sacrificial feast.

Women's festivals that were not supported or sanctioned by the state included the Adonia, traditionally a countercultural festival celebrated privately by women. This festival celebrated the relations of Aphrodite, goddess of love, and Adonis, a young mortal male who died before reaching manhood. At Athens, the celebrations seem to have taken place typically in small, private, all-night parties hosted by women at their homes (and on their roof-tops) (see, e.g., Men. Sam. 46; Ar. Lys. 38998 ), and eating and drinking were probably part of the usual festivities. ${ }^{48}$ Women seem to have held neighbourhood parties in honour of other deities as well: for example, in Aristophanes' Lysistrata, the women's chorus lament that their neighbours cannot provide Boeotian eel for a private celebration (which Henderson calls a 'neighbourhood picnic'49) in honour of Hecate (700-3). The sophist Alciphron of the second or third century A.D., who based his fictive letters largely on Attic comedy, has a fictive hetaira describe a private sacrificial feast as if it were a women's symposium, with reclining, garlands, sweetmeats, songs, jests, perfumes, drinking until dawn, and drunken revelry through the streets to a beloved's house (Ep. Meret. 14.3-7). There are several vase paintings depicting women holding symposia; $;^{50}$ it has sometimes been suggested that such depictions may just be male jokes, but as $M$. Robertson suggests, it also seems 'very likely' that hetairai, at least, held their own symposia. ${ }^{51}$

Impromptu visits to religious sanctuaries seem also to have offered opportunities for women to hold small private picnics and dining parties. Evidence of women dining in religious sanctuaries includes depictions on votive reliefs of women at sacred meals. ${ }^{52}$ Menander's Dyskolos offers perhaps our fullest representation of women holding a picnic in a religious sanctuary. A mother takes her daughter and friends to a rural sanctuary of Pan and the nymphs, where they sacrifice and 
have a luncheon feast which includes wine, mutton, and various other treats $(447-53,438)$. The women also bring rugs on which to recline or sit $(405,420) .{ }^{53}$ The son's comment that his mother is out making sacrifices every day (260-3) suggests that Greek women could engage in such sociable activities seemingly at will. The Greek literary tradition of all-female picnics also includes the famous picnic of Nausicaa and her female attendants, as they wait by the river for clothes to dry (Hom. Od. $6.97-9,76-8)$.

In more established female communities, all-women dining (and drinking) parties probably were not uncommon. For example, on the island of Lesbos in the sixth century B.C., the poet Sappho was the centre of a group of women who gathered together for reasons of affection and also instruction (e.g., in music and poetry), and it is likely that these gatherings also included food and drink on occasion. Sappho fragment 2 (preserved on a potsherd), for example, which includes a call to Aphrodite to pour nectar mingled with the festivities into golden cups, evokes drinking festivities set in a luxuriant sanctuary of Aphrodite. ${ }^{54}$ Also in the Spartan state, where men typically ate dinner not at home but in male messes (Plut. Lyc. 10,12), due to the state's desire for a standing military force, women (in the absence of men at dinnertime) might well have gathered for private dining parties. In the fourth century B.C., Aristotle complains that Spartan women were "indulg[ing] in all sorts of licence and liv[ing] a luxurious life, ${ }^{55}$ and such a life (for a Greek man at least) typically included lavish dining and drinking parties.

Dionysiac rites also provided opportunities for women to drink and eat together, not only in ecstatic, private, all-night celebrations but also in other contexts. ${ }^{56}$ For example, a calendar dated 375-350 B.C. from the Attic deme Erchia indicates that women were to receive and consume the sacrificial meat from the goat-sacrifices to Semele and Dionysus that took place on the 16th of the month Elaphebolion. ${ }^{57}$ Annual celebrations of the Agrionia also seem to have included eating and drinking rituals. Plutarch reports that by his day (late first, early second century A.D.) women at Chaeronea's Agrionia dined together and during the drinking afterwards asked riddles of one another, which calmed them after their ritual search for Dionysus (Quaest. conv. 717a). ${ }^{58}$ (Earlier eating and drinking rituals at the Agrionia, described by Burkert as 'a festival of dissolution and inversion, with a women's uprising, madness, and cannibalistic fantasies', ${ }^{59}$ may have been more ecstatic.) Also, the annual journey of women from Athens (called 
Thyiads) and Delphi to Parnassus to worship Dionysus (Paus. 10.4.2) probably included shared eating and drinking rituals (Pausanias traces this journey back to Homeric times). ${ }^{60}$

\section{Men Attending Women's Parties}

This section presents cases of women's parties that seem to have included men, especially when invited by women guests. The Adonia, especially, seems to have provided opportunities for males to attend female-defined feasts, and male writers seem particularly taken with this aspect of the festival. Thus, for example, Alciphron has a fictive hetaira close a letter to her girlfriend by issuing an invitation to a feast of Adonis, to which she is encouraged to bring her current 'Adonis' (EP. Meret. 14.8), and we also have a fragment from Diphilus' play The Painter that represents a male cook taking a young man to an Adonis feast hosted by a courtesan (ap. Ath. 292d). ${ }^{61}$ In Menander's Samia, a young man happens upon an Adonia hosted by his father's concubine and ends up impregnating the neighbour girl (35-50), and the poet Dioscorides in the third century B.C. wrote several epigrams also focusing on the Adonia as a site for male-female seduction. ${ }^{62}$ Further, at the public Adonia sponsored by Arsinoe in Ptolemaic Alexandria in the third century B.C., males seem to have been included among the expected spectators: thus in Theocritus' Idyll 15 an important male-female encuunter takes place within the ceremonial space of the Adonia (two Syracusan housewives praise ceremonial tapestries and a male bystander ridicules the way they speak). Further, Petrie papyrus 3.142 , dated 250 B.C. at the latest, also seems to suggest that males participated in Adonia celebrations in Ptolemaic Egypt, for the private expenses listed in the papyrus include bath and barber. ${ }^{63}$ Other female-dominated Aphrodite celebrations also seem to have included males on occasion. Thus, for example, an anecdote reports how Gnathaena, a famous fourth-century B.C. hetaira in Athens, invited Diphilus, the New Comedy writer, to a feast at her home in celebration of an Aphrodite festival (Machon ap. Ath. 579e-580a).$^{64}$ So too at the prostitutes' festival of Aphrodite in Corinth, as presented in Alexis' The Girl in Love (ap. Ath. 574b-c), women drank with men.

Celebrations of the Haloa, the bawdy midwinter festival in honour of Demeter and Dionysus mentioned earlier, may not always have excluded men. A fictive hetaira in one of Lucian's Dialogues of 
Courtesans identifies someone by recalling that he drank with her at last year's Haloa festival (1.1). ${ }^{65}$ The incidental nature of her remark suggests that, as in the case of the Adonia, males may not have been excluded from all festivities associated with the Haloa (at least by the second century A.D.). Also, mixed thiasoi (groups of Dionysiac worshippers) that involved initiation were including males by the fifth century B.C., ${ }^{66}$ and the group activities doubtless included eating and drinking rites.

Private women's worship ceremonies also seem to have sometimes included men in celebration feasts after a sacrifice. For example, in Menander's Dyskolos, after the mother and her female friends sacrifice to Pan and the nymphs, the son assumes that he might attend the celebratory lunch and also that he might bring along his new male friend and the friend's male slave $(554-62,611-16)$. The family servant who is helping prepare the meal grumbles at the extra guests but does not express surprise that they are male $(563-70,607-11) .{ }^{67}$ Later, the men join the women in an all-night party in the cave (see, e.g., 855-9, 871, 932-53).$^{68}$ Also in Alciphron's Letters of Courtesans (13), private worship of the nymphs provides an excuse for a party including both males and females: a hetaira invites a group of female friends to bring their male lovers to her lover's country house for a sacrifice and a celebratory feast afterwards.

\section{Women in Charge}

This section focuses on cases of males attending female-defined celebrations and parties where we have evidence that females were clearly in charge. ${ }^{69}$ For example, in Menander's Dyskolos a city woman directs the sacrifice to Pan and the celebratory lunch, and if her son and his friends attend the lunch, they are there as guests. ${ }^{70}$ Alciphron's Ep. Meret. 13 also makes clear the power relations between women and their male guests at a female-defined celebration. Melissa and her girlfriends are in charge of the sacrifice to the Nymphs and also of the feasts that follow (even though their male companions are present): the women decide where the banquet will take place and they also decide what the entertainment will be. Other fictive examples of women-in-charge occasions are Adonis feasts that include men (see Alciphron Ep. Meret. 14; Diphilus ap. Ath. 292d). Also, inscriptional evidence from Magnesia (third century B.C.) shows that women were also in charge of 
mixed groups of worshippers of Dionysus (thiasoi), ${ }^{71}$ and their celebrations probably included food and drink.

Just as powerful men could use dinner parties to advertise power and status, so too women. The most famous example of a powerful woman in charge in fifth-century B.C. Athens is Aspasia, mistress of Pericles and good friend of Socrates, who reportedly encouraged his friends to bring their wives with them to visit her (Plut. Per. 24.3). Aspasia's hospitality would probably have included food and drink, a traditional way to welcome visitors. ${ }^{72}$ Certainly if she had worked for a time as a hetaira, she would have been familiar with customs of symposia and could have drawn on that knowledge in setting up her own entertainments, both for Socrates' friends and their wives and also for others. ${ }^{73}$ (Pericles' relationship with Aspasia was the object of much mockery in fifth-century democratic Athens [see, e.g., Ar. Ach. 516-39], as were elitist dinner parties in general [see, e.g., Ar. Vesp. esp. 1197-325].)

Before the Hellenistic period, the women celebrated in our extant texts for hosting feasts were generally courtesans. For example, the hetaira Gnathaena was perhaps the most famous fourth-century B.C. Athenian woman in charge. Like Aspasia, she too hosted important drinking and dining parties, attended by rich and notable males. Further, like Aspasia, Gnathaena was also celebrated for her ability to manipulate her guests and for her wit. She was even reputed to have matched wits with her favourite lover, the distinguished Athenian New Comedy poet Diphilus (Ath. 579e, 583ef). In the fourth century B.C., there was a tradition of philosophers writing treatises on symposium manners. ${ }^{74}$ Gnathaena is also credited with writing such a treatise, called 'Rule for Dining in Company'. ${ }^{75}$ This treatise exemplifies her assumption of power at her dinner parties, for guests who attended her and her daughter's parties reportedly were expected to follow her rules. The example of Gnathaena shows how women could appropriate a typically male-defined institution and make it their own.

In the Hellenistic age also, the tradition of hetairai hosting lavish dinner parties as a means of self-display continues. A particularly bold example is the lavish dinner hosted by Lamia, an Athenian flute-girl, in honour of her lover, Demetrius Poliorcetes of Macedonia, for she reportedly exacted money from the local citizens to finance the party (Plut. Demetr. 27.2; Lynceus ap. Ath. 101e, 128ab; see also Alciphron Ep. Meret. 16.8).

Respectable Hellenistic women also used lavish feasts to demonstrate power and establish prestige. For example, Archippe, daughter of 
Dikaiogenes, among other beneficent acts, paid for a sacrifice and banquet for the people of Cyme, as recorded in decrees passed by the assembly of Cyme in her honour in the second century B.C. ${ }^{76}$

Hellenistic queens too used the forum of dining parties for self-display and political advantage. The most famous example perhaps is Cleopatra VII, who, on meeting Antony in Tarsus in 41 B.C., hosted a fourday series of royal symposia, each more sumptuous than the last (Socrates of Rhodes $a p$. Ath. 147e-148b) ${ }^{77}$ Another magnificent banquet, supposedly hosted by Cleopatra in Rome for Julius Caesar, is described in detail by the epic poet Lucan (10.108-71).

Queen Arsinoe II's sponsorship of a public Adonia in Alexandria, Egypt, offers another example of a Hellenistic queen using the hosting of parties for political advantage. As noted above, the Adonia was traditionally a countercultural women's festival celebrated in private parties. Arsinoe seems to have taken the innovative step of sponsoring an Adonia in the palace grounds and inviting the public to attend. Theocritus' Idyll 15, our evidence for Arsinoe's Adonia, shows how Arsinoe's sponsorship of a public Adonia, by recognizing and authorizing what was formerly marginalized, highlights Arsinoe's powerful presence at court and in Alexandria's cultural life. ${ }^{78}$

\section{On Equal Terms}

Festivals that provided occasions for men and women to gather together may sometimes have included rituals of feasting and drinking on fairly equal terms, whether the men and women were seated together or separately. For example, as Herodotus' story of Cleobis and Biton suggests, the Argive feast in honour of Hera seems to have included both men and women, during the archaic age at least: thus, when Cleobis and Biton pull a wagon carrying their mother to Hera's temple for a feast, according to Herodotus' Solon, both men and women are there to congratulate them; and Hera rewards the boys for their deed by having them die (happily) in their sleep after they sacrifice and banquet (1.31). Further, when Xenophon established an Artemis sanctuary at Scillus near Olympia in the fourth century B.C., he instituted an annual sacrifice to the goddess 'and all the citizens and the men and women of the neighbourhood participated in the festival' (Anabasis 5.3.9).

Celebrations of the Thargelia (in honour of Apollo) also may have 
included feasts attended by both men and women: for example, there is a story that during the Thargelia that takes place while the Milesians are besieging Naxos, one of the invading captains (Diognetus) falls in love with a Naxian girl (Polycrite), who contrives that during the Thargelia festivities a message be sent to her brothers to attack. ${ }^{79}$ As N. Robertson suggests, 'Since Polycrite and Diognetus are together throughout, we may wonder whether girls and suitors continued to enjoy each other's company at the banquet'. ${ }^{80}$ (The motif of boy meeting girl during religious celebration is, of course, regular in ancient fiction: for example, the fictive Acontius [from Iulis] and Cydippe [from Naxos] meet when they both come to Delos for the annual ox-sacrifice to Apollo [Callim. Aet. 3, frs. 67.5-6].) So too celebrations of gender-inclusive mysteries included feasts for both men and women, although they need not have eaten in the same dining area. ${ }^{81}$ Thus, for example, the Andanian statute reforming the mysteries of Apollo Karneios and Demeter in 92-91 B.C. directs the hieroi (holy men) to share a meal of sacrificial meat with the hierai (holy women), as well as select others, both male and female (including the hierophant's wife and children) ${ }^{82}$ So too by the Hellenistic age, certain Dionysiac rites seem to have included men and women on fairly equal terms, ${ }^{83}$ and these rites probably included some form of eating and drinking.

Wedding feasts offered other occasions on which Greek men and women could gather together and eat and drink on fairly equal terms. ${ }^{84}$ Plutarch's Table-Talk (Quaest. conv.) includes the question 'Why do people invite the most guests to wedding feasts?' (666d). One answer given is that the guest-list becomes large in part because 'many or most of the activities relating to a wedding are in the hands of women, and where women are present it is necessary that their husbands also should be included' (667b). ${ }^{85}$ This statement seems to reflect a long tradition of women's high visibility in Greek wedding processions and other activities, as depicted, for example, in vase paintings dating from the sixth and fifth centuries B.C. ${ }^{86}$ By the fourth century B.C. in Athens, if not necessarily earlier and elsewhere, wedding parties may have placed males and females at separate tables, as suggested by a fragment from Euangelus (probably a New Comedy poet): a father claims to have told his cook to set 'four tables of women and six of men' in preparation for the wedding-feast (Ath. 644d). ${ }^{87}$

The tradition of wedding feasts that included both males and females also has roots in the heroic age: for example, the wedding feast of Peleus and Thetis, which was attended by both male and female deities. ${ }^{88}$ In 
Apollonius of Rhodes's Argonautica, Hera, goddess of marriage, claims to have been in charge of Peleus and Thetis' wedding and wedding feast: she asserts that she gave Thetis Peleus as her husband, summoned all the gods to the wedding feast, and raised the bridal torch (4.805-9). Also, in Homer's Odyssey, when Odysseus stages a noisy wedding party to fool passers by, he includes both men and women (23.130-47). Further, the legendary wedding party of the Lapith king Peirithoüs and Hippodameia includes both male and female guests (the Centaurs become drunk and try to abduct the Lapith women).

Examples from New Comedy reinforce the impression that the tradition of mixed wedding parties seems to have persisted in the Greek world. Thus a fragment of Menander from the play 'Ladies Who Lunch Together' seems to assume that women could attend wedding feasts: 'A clever scheme this, not to get a lot of women together and entertain a crowd, but to get up a wedding, as you have done, for those who eat at home' (ap. Ath. 248a; tr. Gulick) ${ }^{89}$ So too Gomme and Sandbach comment on fragment 209 of Menander: 'the speaker .. . imagines the horrors of a wedding-party where there are present many relations of the bride; a wedding-party, since this is an occasion when men and women drink together'. ${ }^{90}$

As for funerals, the will of Epiktete of Thera shows that at least by 200 B.C. women as well as men were participating in private commemorative feasts for the dead, for Epiktete's will established an annual three-day feast in honour of the Muses and heroes (Epiktete, her husband, and her two sons), and both females and males are named by her will as members of the initial commemorative group. ${ }^{91}$

\section{Conclusion}

Scholarly studies of ancient commensality have traditionally focused mostly on men, and women's roles (beyond hetaira at symposium) are often overlooked. One problem is that our evidence for ancient lives is fairly limited and was generated and preserved mostly by men. Another problem is the weight given to evidence from classical Athens, where respectable women's roles seem to have been more restricted than elsewhere in the Greek world. This paper presents a wide range of evidence, including inscriptions, court cases, ancient histories, vase paintings, literary texts, scholia, and archaeological remains. From this 
evidence we begin to appreciate the variety of women's commensal activities in the ancient Greek world.

In classical Athens the range of commensal activities for respectable, upper-class women appears to have been limited. Yet the evidence in this paper shows that even in classical Athens the social opportunities for women to share food and drink were more varied than generally acknowledged, including such events as luncheons, private parties, wedding banquets, and sacrificial feasts. Outside classical Athens, the range widens still further. It is highly probable that respectable women were included in common feasts among philosophical communities that welcomed women (e.g., the Pythagoreans, Southern Italy, sixth century B.C., and the Epicureans later). Also, it is likely that women in Sappho's circle in Lesbos (sixth century B.C.) shared common meals and threw private drinking parties. In Sparta too, where Spartiate men ate in common messes, it is likely that Spartiate women invited one another to dinner on occasion. Further, during the Hellenistic period, a time of rising social mobility, the range of women's roles at dining and drinking parties was also expanding. Evidence suggests, for example, that respectable women and queens were displaying their power through the sponsorship of lavish public banquets. Even the elitist male-defined symposium, which arose during the archaic age, started opening up to include respectable women, at least by the third century B.C., if not earlier.

Religious festivals provided important occasions for women to share food and drink with one another in the ancient Greek world, as elsewhere. These included not only publicly sponsored women's festivals such as Athens' Thesmophoria, which featured a major women's feast, but also countercultural women's festivals such as the Adonia, traditionally celebrated through private parties. Archaeological excavations have uncovered dining buildings in sanctuaries of women's worship, which suggest women's banquets. Also, even at male-dominated religious festivals, women might receive shares of the sacrificial meat and attend the sacrificial feasts. Further, our evidence also shows women holding private sacrifices and including men in the meals afterwards. Finally, certain religious celebrations that included both men and women seem to have provided opportunities for men and women to share meals on fairly equal terms.

This paper shows that the traditional view of women's commensality in the ancient Greek world is too narrow. The evidence makes it clear that women were active in commensal activities, both inside classical 
Athens and certainly outside. This survey of the variety of Greek women's drinking and dining activities emphasizes the need to include women more centrally in histories of commensality and sociality in the ancient Greek world.

\section{NOTES}

1. Useful collections of articles on the ancient symposium include O. Murray, ed., Sympotica: a Symposium on the Symposion (Oxford, 1990); W. J. Slater, ed., Dining in a Classical Context (Ann Arbor, 1991); O. Murray and M. Tecuşan, edd., In Vino Veritas (London, 1995).

2. O. Murray, 'Forms of Sociality', in J.-P. Vernant, ed., The Greeks, tr. C. Lambert and T. L. Fagan (Chicago, 1995), 230. See also, e.g., E. Fantham, H. P. Foley, N. B. Kampen, S. B. Pomeroy, H. A. Shapiro, Women in the Classical World: Image and Text (New York, 1994), 280.

3. On Athenian dining customs, with attention to women's roles, see A. Dalby, in G. Mars and V. Mars, edd., Food: Culture and History, vol. i (London, 1993), $165 \mathrm{ff}$.

4. For example, as Page points out in a discussion of Sappho fr. 31, 'We have no reason to suppose that in Lesbos, at the beginning of the sixth century B.C., a man might not sit opposite a woman and converse with her, whether he loved her or not and whether he was married to her or not' (D. Page, Sappho and Alcaeus: an Introduction to the Study of Ancient Lesbian Poetry [1955; reprint, Oxford, 1979], 32).

5. For the use of the term symposium 'to denote not only the drinking phase but the preceding dining phase as well, i.e. the entire feast', see B. Bergquist, in Murray (n. 1 above), 37.

6. On ancient Greek public banquets (and their linkage with male citizenship), see P. S. Pantel, La Cité au banquet: Histoire des repas publics dans les cités grecques (Rome, 1992).

7. As Hunter observes, 'it is clear that New Comedy characters are placed in sinuations which are within the possible experience of the audience' (R. L. Hunter, The New Comedy of Greece and Rome [Cambridge, 1985], 12).

8. See O. Murray, in E. Gabba, ed., Tria corda: Scritti in onore di Arnaldo Momigliano (Como, 1983), 259 ff.; Early Greece ${ }^{2}$ (Cambridge [Mass.], 1993), 47-8.

9. Fraenkel contrasts this with Athenian custom: 'The part played by the daughter in the sacrificial ritual of a company of men consisting by no means solely of her near relations ... would be hardly conceivable within the limits of Athenian custom' (E. Fraenkel, ed., Aeschylus: Agamemnon, reprint, with corrections, 3 vols. [Oxford, 1962], vol. ii 141 n. 245 ff.).

10. See too, e.g., the Codrus Painter's red-figure cup (Vulci; London, British Museum E 82; $A R V^{2}$ 1269.3) depicting goddesses (seated) and gods (reclining) at a symposium (pictured in M. Robertson, The Art of Vase-Painting in Classical Athens [Cambridge, 1992], 220 fig. 227).

11. On Sappho's response to Homeric stories, see, e.g., J. Winkler, in H. P. Foley, ed., Reflections of Women in Antiquity (New York, 1981), esp. $64 \mathrm{ff}$.

12. See, e.g., Murray (n. 8 above, in E. Gabba), 263-4; id., in R. Hägg, ed., The Greek Renaissance of the Eighth Century B.C.: Tradition and Innovation (Stockholm, 1983), 198. For a useful discussion of reclining vs. seated dining (with attention to gender: among women 'sitting was the preferred position'), see F. Cooper and S. Morris, in Murray (n. 1 above), esp. $77 \mathrm{ff}$.

13. On how women's 'presence at men's drinking-parties exposed them to importuning, mauling, kidnapping (an occasion for fighting between rival males)', see K. J. Dover, Greek Popular Morality in the Time of Plato and Aristotle (Berkeley, 1974), 210. On depictions of sexual abuse of females on painted sympotic ware, see E. C. Keuls, The Reign of the Phallus: Sexual Politics in Ancient Athens (New York, 1985), $174 \mathrm{ff}$. On the relative rarity of depictions of sexual abuse of males (by males), see R. F. Sutton, Jr., 'Pornography and Persuasion on Attic Pottery', in A. Richlin, ed., Pornography and Representation in Greece and Rome (New York, 1992), $12 \mathrm{ff}$. For a fictive flutegirl's vantage on male violence (due to sexual jealousy) at a Greek dinner party, see Lucian Dial. Meret. 15.

14. Thus, in the fourth century B.C., Demosthenes ( $19.196 \mathrm{ff}$.) discredits Aeschines in court by reporting how Aeschines had a woman beaten almost to death for refusing to sing at a symposium 
(another symposiast intervenes to save her life). Aeschines' response (2.158) shows that he recognizes that such abusive behaviour (if true) would bring public disgrace.

15. This argument was advanced, for example, against Neaira, a Corinthian prostitute whom Stephanos, an Athenian citizen, had claimed as his lawful wife (Dem. 59.33, Against Neaera). See also, e.g., Isaeus 3.13-14 (On the Estate of Pyrrhus).

16. On hetairai at symposia, see, e.g., K. Schneider, 'Hetairai', $R E$, esp. 1347-50; Keuls (n. 13 above), esp. $160 \mathrm{ff}$; I. Peschel, Die Hetäre bei Symposion und Komos in der attisch-rotfigurigen Vasenmalerei des 6.-4. Fahrh. v. Chr. (Frankfurt am Main, 1987).

17. The English translation is taken from J. C. Rolfe, ed. with translation, Cornelius Nepos (1929; Cambridge [Mass.], 1984), 5.

18. Men. ap. Ath. 71 ef; F. H. Sandbach, ed., Menandri Reliquiae Selectae ${ }^{2}$ (Oxford, 1990), 304-5 (no. 209).

19. The English translation, rev., is taken from E. S. Forster, ed. with translation, Isaeus (Cambridge [Mass.], 1927), 85.

20. For the claim regarding certain respectable Athenian women that they were known by not only relatives but also clansmen and most of the demesmen, see Isaeus 6.10 .

21. For the story of Hipparchia, see Diog. Laert. 6.96-8.

22. For discussion, see M. M. Henry, Prisoner of History: Aspasia of Miletus and Her Biographical Tradition (New York, 1995), esp. $24 \mathrm{ff}$.

23. On the Pythagorikai, see Diog. Laert. 8.41. On the admission of women to the Epicurean community, see, e.g., B. Frischer, The Sculpted Word: Epicureanism and Philosophical Recruitment in Ancient Greece (Berkeley, 1982), $61 \mathrm{ff}$. For discussion of women philosophers, see S. B. Pomeroy, Goddesses, Whores, Wives, and Slaves: Women in Classical Antiquity (New York, 1975), $131 \mathrm{ff}$;; R. Hawley, in L. J. Archer, S. Fischler, and M. Wyke, edd., Women in Ancient Societies: 'An Illusion of the Night' (New York, 1994), $70 \mathrm{ff}$.

24. On the topic of recruitment to the Epicurean community, Frischer comments that 'It would be hard to overemphasize the appeal of a school that was willing to grant females full rights of participation in all of its activities' (Frischer [n. 23 above], 62).

25. Pomeroy (n. 23 above), 81. For Agariste's testimony, see Andocides 1.16; cf. D. MacDowell, Andokides: On the Mysteries (Oxford, 1962), 75 n. 16.

26. See, e.g., Pomeroy (n. 23 above), 125-6, 130.

27. On Arsinoe's rotunda at Samothrace, see J. R. McCredie et al., The Rotunda of Arsinoe, vol. vii of K. Lehmann and P. W. Lehmann, edd., Samothrace: Excavations Conducted by the Institute of Fine Arts of New York University (Princeton, 1992). On the significance of Arsinoe's sponsorship of a public Adonia, see section 5 below.

28. See, e.g., S. B. Pomeroy, Women in Hellenistic Egypt: from Alexander to Cleopatra (New York, 1984), esp. $83 \mathrm{ff}$.

29. On Hellenistic poetry's reflection of contemporary social and gender issues, see J. B. Burton, Theocritus's Urban Mimes: Mobility, Gender, and Patronage (Berkeley, 1995).

30. On non-elite symposia before the Hellenistic period, see E. Pellizer, in Murray (n. 1 above), 181.

31. For discussion of gender and social issues raised in Idyll 14, see J. B. Burton, GRBS 33 (1992), esp. 236 ff.; id. (n. 29 above), esp. 25-6, 46 ff.

32. A. Cameron, 'Asclepiades' Girl Friends', in Foley (n. 11 above), 277; reprinted in an expanded version as 'Appendix C' in A. Cameron, Callimachus and his Critics (Princeton, 1995), 497. For an interesting parallel, see the custom Theopompus notes among the Etruscans: 'women dine not with their husbands, but with any men who happen to be present, and they pledge with wine any whom they wish' (ap. Ath. 517d; tr. C. B. Gulick, ed. with translation, Athenaeus: the Deipnosophists, 7 vols. [Cambridge, Mass., 1927-41], vol. v, p. 329).

33. For discussion, see Pantel (n. 6 above), esp. $126 \mathrm{ff}$., 130.

34. For the inscription, with commentary, see W. S. Ferguson, Harv. Theol. Rev. 37 (1944), esp. 73 ff., 81 .

35. Ferguson (n. 34 above), 78, 81. Detienne suggests that the women here 'are admitted into the larger circle of commensals only by the intermediary of someone having the right to obtain for them this favored treatment' (M. Detienne, in M. Detienne and J.-P. Vernant, edd., The Cuisine of Sacrifice among the Greeks, tr. P. Wissing [Chicago, 1989], 132). For a reminder that it is not certain that the women actually attended the sacrifice, see R. Osborne, CQ 43 (1993), 400. 
36. See C. Rolley, 'Le Sanctuaire des Dieux Patrôoi et le Thesmophorion de Thasos', Bulletin de correspondance hellenique 89 (1965), 447, 462-3. For the suggestion that only wives could participate, see Detienne (n. 35 above), 131; on the inclusion of single women (both widows and spinsters), see Osborne (n. 35 above), 392, 405.

37. Plut. Thes. 23. 2-3; for discussion, with references, see H. W. Parke, Festivals of the Athenians (Ithaca, 1977), 77-8.

38. For a private celebration of the rural Dionysia, see, e.g., Ar. Ach. 237-79 (Dikaiopolis, his daughter, and two family slaves hold a sacrificial procession, and Dikaiopolis' wife supervises).

39. For further discussion of these examples, see Dalby (n. 3 above), 172.

40. On the exclusion of males from this festival, see, e.g., Ar. Thesm.; W. Burkert, Greek Religion, tr. J. Raffan (Cambridge [Mass.], 1985), 242.

41. On females presiding at the Thesmophoria, see Ar. Thesm. $372 \mathrm{ff}$., Isaeus 8.19; on males financing the Thesmophoria, see Men. Epit. 749, Isaeus 3.80.

42. Paus. 4.17.1; for discussion, see Detienne (n. 35 above), 130; see also Osborne (n. 35 above), 401 .

43. On male sponsorship of the Skira, see Men. Epit. 749-50. On female activities at the Skira, see W. Burkert, Homo Necans: the Anthropology of Ancient Greek Sacrificial Ritual and Myth, tr. P. Bing (Berkeley, 1983), esp. 145. On the Skira, see also Parke (n. 37 above), 156 ff.; L. Deubner, Attische Feste (1932; reprint Berlin, 1956), $40 \mathrm{ff}$.

44. Our best source for the Haloa festival is H. Rabe, ed., Scholia in Lucianum (1906; reprint, Stuttgart, 1971), 279 ff. (to Dial. Meret. 7.4); for an English translation, with discussion, see J. J. Winkler, 'The Laughter of the Oppressed: Demeter and the Gardens of Adonis', in The Constraints of Desire: the Anthropology of Sex and Gender in Ancient Greece (New York, 1990), 194-5.

45. For discussion, see Detienne (n. 35 above), 132-3. On priestesses consuming the innards of sacrificial victims, see Osborne (n. 35 above), 401-2.

46. For the inscription, see F. Sokolowski, Lois sacrees de l'Asie Mineure (Paris, 1955), $170 \mathrm{ff}$., no. 73; for discussion of the political nature of this sacrifice, see Detienne (n. 35 above), 136.

47. On dining quarters at Brauron, with references, see $M$. S. Goldstein, The Setting of the Ritual Meal in Greek Sanctuaries: 600-300 B.C. (Ann Arbor, 1978), $114 \mathrm{ff}$. On dining buildings in the sanctuary of Demeter at Corinth, see N. Bookidis and J. E. Fisher, Hesperia 41 (1972), $288 \mathrm{ff}$.

48. All-night festivals, considered characteristic of Greek women (see Men. Dysk. 857), often included dining and drinking (thus the Thesmophoria, the Haloa, and the Skira, as discussed above). Adonia festivals, like Dionysia, seem also to have encouraged a mixing of social classes. For (fictive) married women attending Adonia hosted by less respectable women, see Men. Sam. 35-41 (a married neighbour woman and her daughter attend a concubine's Adonia); see also Alciphron, Ep. Meret. 14.2-3, 8.

49. J. Henderson, ed., Aristophanes: Lysistrata (Oxford, 1987), 162 n. 700-5.

50. For visual illustrations of women's symposia, see, e.g., the Curtis Painter's cup (Basel, Market 1877) depicting partially unclothed, reclining women, with cups and musical instruments (pictured in Keuls [n. 13 above], 166 fig. 140). See also the psykter, with Euphronios' signature (Leningrad, Hermitage 644, $A R V^{2}$ 16.15), depicting unclothed, reclining women, with cup and flute (pictured in J. Boardman, Athenian Red Figure Vases: the Archaic Period [New York, 1975], 40 fig. 27); the cup (Madrid, Museo Arqueológico Nacional 11.267, dated 520-510 B.C.) depicting unclothed, reclining women, with cup and flute (pictured in Fantham et al. [n. 2 above], 118 fig. 3.26); Phintias' red-figure hydria (Munich 2421) depicting partially unclothed, reclining women playing kottabos (pictured in M. Robertson [n. 10 above], 27 fig. 20). Cf. the Etruscan black-figure 'Pontic' amphora that depicts clothed, reclining women banqueting (New York, Metropolitan 55.7; pictured in J. Charbonneaux, R. Martin, F. Villard, Archaic Greek Art 1620 $480 \mathrm{BC}$, tr. J. Emmons and R. Allen [New York, 1971], 98 fig. 108).

51. M. Robertson (n. 10 above), 27

52. On votive relief gifts from Eleusis, Delphi, Thasos, and Lesbos that depict women at sacred meals, see Cooper and Morris (n. 12 above), 80 (Plate 6 shows a votive relief from Thasos that depicts reclining men in the upper register and seated women in the lower).

53. On seated dining (rather than reclining) as the custom for ancient Greek women, see J.-M. Dentzer, Le Motif du banquet couché dans le Proche-Orient et le monde grec du VII" au IV siècle avant 9.-C. (Paris, 1982), 432; see also Cooper and Morris (n. 12 above), 80-1.

54. An additional phrase 'for my boon-companions and yours' may have further strengthened 
the sympotic tone of this fragment: see Ath. 463e, where Plutarch cites Sappho's call to Aphrodite with this phrase added (on the possibility that 'this phrase may also have been in S.'s poem', see D. A. Campbell, ed. with translation, Greek Lyric, vol. i [Cambridge, Mass., 1982], 59). This additional phrase, if originally in the feminine, as elsewhere in Sappho (see, e.g., Ath. 571d), would underscore the female camaraderie of this drinking occasion.

55. Arist. Pol. 1269b6; translation by E. Barker, The Politics of Aristotle, reprint (London, 1958), 75.

56. There are many vase paintings showing women involved in Dionysiac rites: for an example of women serving one another wine from a stamnos, see C. Bérard, C. Bron, J.-L. Durand, F. Frontisi-Ducroux, F. Lissarrague, A. Schnapp, and J.-P. Vernant, $A$ City of Images: Iconography and Society in Ancient Greece, tr. D. Lyons (Princeton, 1989), 19 fig. 18 (Ashmolean Museum, Oxford). On ritual maenadism, see A. Henrichs, HSCP 82 (1978), 121 ff.; see also R. S. Kraemer, Her Share of the Blessings: Women's Religions among Pagans, fews, and Christians in the Greco-Roman World, reprint (New York, 1993), $36 \mathrm{ff}$.

57. See G. Daux, 'La Grande Démarchie: un nouveau calendrier sacrificiel d'Attique (Erchia)', Bulletin correspondance hellénique 87 (1963), esp. 606, 609. For discussion, see also Detienne (n. 35 above), 132; Osborne (n. 35 above), 399.

58. On the calming effect of the eating and drinking rituals at Plutarch's Agrionia, see Burkert (n. 43 above), 176: 'Here, everything happens between women, and they themselves direct the shift from wild behavior to that controlled by the Muses.'

59. Burkert (n. 40 above), $163 \mathrm{f}$.

60. Cf. the story of how the women of Amphissa fed the maenadic Thyiads of Delphi when they awoke in Amphissa's marketplace, during the Sacred War (Plut. Mul. virt. 13, 249ef).

61. For discussion of these two passages, see also M. Detienne, The Gardens of Adonis: Spices in Greek Mythology, tr. J. Lloyd (Atlantic Highlands [N.J.], 1977), 65.

62. Dioscorides Epigrams 3 and 4 Gow and Page (= A.P. 5.53 and 5.193); see too Ov. Ars. Am. 1.75 .

63. For discussion, see G. Glotz, REG 33 (1920), 169 ff. (for a summary, see A. S. F. Gow, Theocritus ${ }^{2}$ [Cambridge, 1952], ii. 262 ff.).

64. For Greek text with commentary, see A. S. F. Gow, ed., Machon: the Fragments (Cambridge, 1965), fr. 16.

65. For the suggestion that this was a private party in celebration of the Haloa (and not the sanctuary feast itself), see A. C. Brumfield, The Attic Festivals of Demeter and their Relation to the Agricultural Year (Salem [N.H.], 1981), 115.

66. See, for example, the initiation of Scyles, a Scythian king, in Greek Olbia, mid-fifth century B.C. (Hdt. 4.78-80). On male participation in mixed thiasoi (groups of Dionysiac worshippers), see Burkert (n. 40 above), 291; A. Henrichs, in H. D. Evjen, ed., Mnemai: Classical Studies in Memory of Karl K. Hulley (Chico, 1984), esp. 70-1; Kraemer (n. 56 above), 38 ff.

67. The father also expects to attend the lunch, but arrives too late (Men. Dysk. 775-80). For the view that the men and women ate together at this luncheon, see A. W. Gomme and F. H. Sandbach, Menander: a Commentary (Oxford, 1973), 228 n. 608, 265 n. 871. For the view that the men and women ate separately (women before men), see A. Dalby, Siren Feasts: a History of Food and Gastronomy in Greece (London, 1996), 5.

68. On Gorgias' reluctance to join respectable women at a 'wine-party', see Gomme and Sandbach (n. 67 above), 265 n. 871 ; see also E. W. Handley, The Dyskolos of Menander (Cambridge [Mass.], 1965), 282 n. 871f, who links Gorgias' hesitation with his rusticity: 'A party of this kind, with ladies present, is something outside his experience'. On male vs. female activity on this occasion, see P. Borgeaud, The Cult of Pan in Ancient Greece, tr. K. Atlass and J. Redfield (Chicago, 1988), 168. For the suggestion that 'The distinction between a drinking party for the men and an all-night revel for the women is here one of name rather than nature . . ; they sit separately, but share the same celebration', see Handley, op. cit., 280-1 n. 856-9.

69. For women presiding over all-women feasts (such as at the Thesmophoria and the Skira), see section 3.

70. As Borgeaud emphasizes, 'the women are in charge; they make the rules and determine the sequence of events' (Borgeaud [n. 68 above], 168).

71. For discussion of $I$. Magn. 215, with attention to the use of the masculine form kataibatai, see Henrichs (n. 56 above), esp. 133-4. 
72. On this tradition, see, e.g., W. Arend, Die typischen Scenen bei Homer (Berlin, 1933), 34 ff.; see also A. S. Hollis, Callimachus: Hecale (Oxford, 1990), $341 \mathrm{ff}$.

73. On Aspasia as hetaira, see Ath. 533d; on Aspasia as bawd, see Ar. Ach. 526-7, Plut. Per. 32.1.

For discussion of Aspasia's status, see, e.g., Henry (n. 22 above), esp. $26 \mathrm{ff}$.

74. For example, Aristotle wrote a treatise on manners as well as one on drunkenness (see Ath. $186 \mathrm{~b}, 464 \mathrm{c}, 496 \mathrm{f}$ ), and Xenocrates (another pupil of Plato) also wrote a treatise on symposium manners (Ath. 186b).

75. On Gnathaena's treatise, see Ath. 585ab; the title of the treatise here is taken from Gulick (n. 32 above), vol. vi, p. 155 (Ath. 585b).

76. On the decrees passed in honour of Archippe, see J. Robert and L. Robert, 'Bulletin épigraphique', $R E G 81$ (1968), 504 ff., nos. 444, 445; see also Pomeroy (n. 23 above), 125.

77. See also Plut. Ant. 26.6; for discussion, see P. M. Martin, Antoine et Cléopâtre: la fin d'un rêve (Paris, 1990), 132; L. Hughes-Hallett, Cleopatra: Histories, Dreams and Distortions (New York, 1990), $63 \mathrm{ff}$. Both Lamia's and Cleopatra's parties are cited in a discussion of 'displays of excess' as a 'historiographical motif' (G. Paul, in Slater [n. 1 above], 162).

78. On the public nature of Arsinoe's Adonia, see Burton (n. 29 above), esp. $134 \mathrm{ff}$.

79. See Plut. Mul. virt. 17, 254b-f (FGrH 500 F1); Parth. Amat. Narr. 9 (Andriskos FGrH F2).

80. N. Robertson, in Slater (n. 1 above), 43.

81. On possible dining arrangements, both separate and joint, for men and women in Demeter's sanctuary at Corinth, see N. Bookidis, in Murray (n. 1 above), 91 .

82. For the inscription, with commentary, see F. Sokolowski, Lois sacrées des cités grecques (Paris, 1969), 120 ff. (esp. 126, no. 65, lines 95-8); on the inscription's shared sacrificial feast, see Bookidis (n. 81 above), 91; on the inscription's significance, see also Burkert (n. 40 above), 279.

83. As Henrichs notes, 'By the third century B.C., joint participation in non-maenadic Dionysiac rites by men and women alike must have been the norm rather than an exception' (Henrichs [n. 66 above], 70).

84. On the presence of women at wedding feasts, see J. H. Oakley and R. H. Sinos, The Wedding in Ancient Athens (Madison, 1993), 22 ff.; Cooper and Morris (n. 12 above), 80 n. 46. On the probable absence of women from the sacrificial feast given during the Apaturia, a festival of the phrateres (clansmen), to mark new marriages, see Parke (n. 37 above), 89-90; for the view that the husband introduced his new wife to his phrateres on this occasion, see Burkert (n. 40 above), 255. Cf. Murray (n. 2 above), 230: 'There is no evidence to suggest that they [Greek citizen women] even attended wedding feasts and funeral feasts'.

85. The English translation is taken from H. B. Hoffleit, ed. with translation, Plutarch's Moralia, vol. viii (Cambridge [Mass.], 1969), 335.

86. For illustrations, see Oakley and Sinos (n. 84 above).

87. On this citation, see also, e.g., Oakley and Sinos (n. 84 above), 22. For separate couches of men and women at a Greek wedding feast, see too Lucian Convivium 8.

88. See, e.g., Eur. Iph. Aul. 1036-79; Ap. Rhod. 4.805-9. See also the visual representations on the François vase and two dinoi of Sophilos (e.g., J. Boardman, Athenian Black Figure Vases [London, 1974], illustrations 24, 25, and 46). For discussion of Sophilos' dinoi, with good pictures, see D. Williams, Greek Vases in the F. Paul Getty Museum, vol. i (Malibu [Calif.], 1983), esp. 22 ff.

89. Gulick (n. 32 above), vol. iii, p. 117.

90. Gomme and Sandbach (n. 67 above), 693.

91. For the inscription, see $I G$ 12.3.330; for a French translation with commentary, see R. Dareste, B. Haussoullier, and T. Reinach, Recueil des inscriptions juridiques grecques, 2d series (Paris, 1898; Rome, 1965), 77 ff.; for discussion, see, e.g., R. Garland, The Greek Way of Death (Ithaca, 1985), $108 \mathrm{ff}$. On the little we know regarding the perideipnon (funeral feast), see D. C. Kurtz and J. Boardman, Greek Burial Customs (Ithaca, 1971), 146. 